\title{
Purification and properties of cyclic AMP-dependent protein kinase from rat epididymis
}

\author{
R. Biswas and G. C. Majumder \\ Indian Institute of Chemical Biology, Calcutta-700032, India
}

\begin{abstract}
Summary. Two protein kinases (I and II: EC 2.7.1.37) that show a high degree of substrate specificity for protamine rather than histones, phosvitin and casein, were partly purified from rat epididymal tissue. The enzymes were present in the cytosol because $>80 \%$ of the enzymic activity was recovered in the soluble fraction. The kinases required $\mathrm{Mg}^{2+}$ for activity although $\mathrm{Co}^{2+}$ and $\mathrm{Mn}^{2+}$ were partial substitutes. $\mathrm{Zn}^{2+}(1 \mathrm{~mm})$ inhibited nearly completely the activity of the enzymes. Both the kinases showed high affinity for activation with cyclic AMP compared to other cyclic nucleotides. Amino acid analysis of ${ }^{32} \mathrm{P}$-labelled protamine product revealed that the kinases transfer the terminal phosphate of ATP to serine residues of the protein. The isoenzymes I and II showed certain differences in relation to their hydroxyapatitechromatography profiles, $\mathrm{pH}$ activation profiles, heat sensitivity and $K_{\mathrm{m}}$ for ATP and cyclic AMP.
\end{abstract}

\section{Introduction}

Mammalian spermatozoa are incapable of fertilizing eggs when they first leave the testis. The cells mature in the epididymis before they acquire the capacity for forward motility and fertility. During puberty the epididymis undergoes androgen-dependent growth with differentiation of ciliated epithelial cells which participate in the subsequent transport and maturation of the male gametes (Hamilton, 1975). The molecular mechanisms of these orderly developmental changes are largely unknown.

Protein phosphorylation may serve as an important mechanism for the regulation of cellular functions (Corbin, Reimann, Walsh \& Krebs, 1970; Langan, 1973; Walsh \& Cooper, 1979). Phosphorylation of nuclear proteins has been implicated in the selective expression of genes during hormone-dependent cell differentiation (Kleinsmith, 1975; Turkington, Majumder, Kadohama, MacIndoe \& Frantz, 1973). It has been demonstrated that there is a marked alteration in the pattern of phosphorylation of rat epididymal nuclear acidic proteins during development in vivo and these patterns of protein phosphorylation are dependent on the action of testosterone (Kadohama \& Turkington, 1974). A cyclic AMP-dependent protein kinase activity (EC 2.7.1.37), that causes phosphorylation of model protein substrates, has been detected in crude epididymal extracts of rats (Bernard \& Wassermann, 1972). However, the epididymal protein kinase has not been purified and little is known about its characteristics. We have therefore partly purified and characterized two cyclic AMP-dependent protein kinase isoenzymes from the rat epididymis.

\section{Materials and Methods}

Chemicals. [ $\left.{ }^{32} \mathrm{P}\right]$ Orthophosphoric acid was purchased from Bhaba Atomic Research Centre, Bombay, India. NADH, adenosine 3',5'-monophosphate (cyclic AMP), calf thymus whole 
histones, phosvitin, $p$-chloro-mercuriphenylsulphonic acid and theophylline were from Sigma (St Louis, Missouri, U.S.A.). Protamine sulphate was purchased from the Biochemicals Unit of the V.P. Chest Institute, New Delhi, India. Casein (bovine) was generously supplied by Professor N. C. Ganguli of the National Dairy Research Institute, Karnal, India. DEAE-Sephadex was a product of Pharmacia (Uppsala, Sweden) and hydroxyapatite was obtained from Bio-Rad (Richmond, California, U.S.A.). $\left[\gamma^{32} \mathrm{P}\right]$ ATP was prepared by the method described by Majumder \& Biswas (1979). The specific activity of the $\left[\gamma_{-}{ }^{32} \mathrm{P}\right]$ ATP preparation was approx. $3 \mathrm{Ci} / \mathrm{mmol}$.

Purification of epididymal cytosolic protein kinases. Epididymides from adult rats were minced thoroughly and dispersed in a $4 \mathrm{mM}$-sodium glycerophosphate- $\mathrm{HCl}, \mathrm{pH} 6 \cdot 5-0 \cdot 15$ $\mathbf{M}-\mathrm{KCl}$ buffer $(10 \mathrm{ml} / \mathrm{g}$ tissue) with gentle stirring for $5 \mathrm{~min}$ to remove epididymal fluid containing spermatozoa that would have been present in the epididymal lumen. The supernatant fluid containing spermatozoa and epididymal plasma was poured away. This procedure for the removal of epididymal fluid was repeated twice more. The washed tissue was then homogenized in the same buffer $(1 \mathrm{~g} / 10 \mathrm{ml})$ and the homogenate was filtered through ten layers of cheese-cloth. To determine the degree of contamination of the washed tissue with epididymal fluid, the numbers of spermatozoa were determined in the extracted fluid and the tissue homogenate. (The sperm cells remained mostly intact or only partly damaged during homogenization.) By the above washing procedure more than $99 \%$ of spermatozoa, and consequently the epididymal plasma in which the cells were suspended, was removed from the epididymal tissue.

The homogenate was centrifuged at $22000 \mathrm{~g}$ for $60 \mathrm{~min}$ and the sediment was discarded (Step 1). The resulting supernate was dialysed against 20 volumes of $15 \mathrm{~mm}$-Tris-HCl, $\mathrm{pH}$ 7.0-50 mM-2-mercaptoethanol-15\% glycerol (Buffer A) with two changes of the buffer and then centrifuged at $22000 \mathrm{~g}$ for $10 \mathrm{~min}$. The resulting supernate was subjected to chromatography on a column of DEAE-Sephadex $(11.5 \times 0.8 \mathrm{~cm})$, previously equilibrated with Buffer A. The column was washed with $20 \mathrm{ml}$ equilibrating buffer before elution with a linear gradient of $\mathrm{KCl}(0-0.75 \mathrm{M})$ in a total volume of $150 \mathrm{ml}$ buffer. Fractions $(3 \mathrm{ml})$ were collected at the rate of $20 \mathrm{ml} / \mathrm{h}$ (Step 2). The fractions containing the major enzymic peak (kinase B) were pooled and dialysed against 5 mM-potassium phosphate, $\mathrm{pH}$ 7.0-50 mM-2-mercaptoethanol-10\% glycerol (Buffer B). The dialysed enzyme preparation was applied to a column of hydroxyapatite $(4.5 \times 0.8 \mathrm{~cm})$, previously equilibrated with Buffer $\mathrm{B}$. The column was washed with $15 \mathrm{ml}$ of Buffer B and then eluted with a linear gradient of potassium phosphate $(0.005-1.0 \mathrm{M})$ in a total volume of $150 \mathrm{ml}$ buffer. Fractions $(2 \mathrm{ml})$ were collected at the rate of $20 \mathrm{ml} / \mathrm{h}$.

Assay of protein kinase. The activity of protein kinase was measured by a slight modification of the method described previously (Majumder \& Turkington 1972). The standard incubation medium contained $10 \mu \mathrm{mol}$ sodium $\beta$-glycerophosphate- $\mathrm{HCl}, \mathrm{pH} 6.5,4 \mu \mathrm{mol} \mathrm{MgCl}_{2}, 30 \mathrm{nmol}$ EGTA, $0.6 \mu \mathrm{mol}$ theophylline, $1 \mathrm{nmol}$ cyclic AMP, $2 \mu \mathrm{mol} \mathrm{NaF}, 3 \mathrm{nmol}\left[\gamma_{-}{ }^{32} \mathrm{P}\right] \mathrm{ATP}(8 \times$ $10^{4}-20 \times 10^{4}$ c.p.m.), $0.1 \mathrm{mg}$ protamine sulphate and the enzyme in a total volume of $0.2 \mathrm{ml}$. The incubation was carried out at $37^{\circ} \mathrm{C}$ for $20 \mathrm{~min}$ and the reaction was stopped by the addition of $0.2 \mathrm{ml} 1.5 \%$ casein- $2.5 \mathrm{~mm}$-inorganic phosphate-2 $\mathrm{mM}$ ATP and $4 \mathrm{ml} 15 \%$ trichloroacetic acid (TCA). The resulting precipitate was processed for the assay of radioactivity in protein (Majumder, 1978). The samples were counted for ${ }^{32} \mathrm{P}$ in a liquid scintillation spectrometer (Packard) in toluene-0.4\% 2,5-diphenyloxazole-0.005\% 1,4-bis[2,(5(phenyloxazole)]benzene scintillation fluid. Systems lacking the enzyme preparation were included as blanks in all assays. One unit of the enzyme was defined as the amount of activity which caused the transfer of 1 pmol ${ }^{32} \mathrm{P}$ from $\left[\gamma-{ }^{32} \mathrm{P}\right] \mathrm{ATP}$ to the recovered protein under the standard assay conditions.

Preparation of ${ }^{32} P$-labelled protamine. Protamine was enzymically labelled by phosphorylating it with the isolated epididymal protein kinases under the standard assay conditions. After the 
incubation the reaction was arrested with the addition of $5 \mathrm{ml} \mathrm{10 \%} \mathrm{TCA.} \mathrm{The} \mathrm{precipitate} \mathrm{was}$ collected by centrifugation and washed successively with $5 \%$ trichloroacetic acid, ethanol, ethanol: ether $(3: 1 \mathrm{v} / \mathrm{v})$ and ether.

Polyacrylamide gel electrophoresis. ${ }^{32} \mathrm{P}$-Labelled protamine prepared by the above procedure was analysed by polyacrylamide gel electrophoresis (Paynim \& Chalkley, 1969). After the electrophoresis, the gels were stained with Amido black and destained in $7.5 \%$ acetic acid. Finally the gels were sectioned and the gel slices were dissolved in $30 \% \mathrm{H}_{2} \mathrm{O}_{2}$ before counting in Bray's solution (Bray, 1960) in a liquid scintillation spectrometer (Packard).

Subcellular fractionation. Washed epididymides were homogenized as described above and the subcellular fractions were isolated from the homogenates by a differential centrifugation technique (Hogeboom, 1955). The homogenates were centrifuged at $1000 \mathrm{~g}$ for $15 \mathrm{~min}$ to sediment nuclei. Mitochondria were isolated from the supernatant by centrifugation at $14000 \mathrm{~g}$ for $15 \mathrm{~min}$ and microsomes were isolated by centrifugation at $100000 \mathrm{~g}$ for $60 \mathrm{~min}$. The particulate fractions were washed with the homogenizing medium and finally suspended in 5 mM-potassium phosphate, $\mathrm{pH} 7 \cdot 0-50 \mathrm{~mm}-2$-mercaptoethanol-30\% glycerol buffer. All the fractions were dialysed against the same buffer and protein kinase activities in these fractions were then determined under the standard assay conditions.

Other analytical methods. ${ }^{32} \mathrm{P}$-labelled protamine was hydrolysed in $2 \mathrm{~N}-\mathrm{HCl}$ in a boiling water bath for $12 \mathrm{~h}$ (Turkington \& Riddle, 1969). $\mathrm{HCl}$ was removed under vacuum and the hydrolysate was subjected to paper electrophoresis at room temperature on Whatman No. 1 filter paper strips using $8 \%$ formic acid as the electrophoresis buffer (Majumder \& Turkington, 1972). Unlabelled $o$-phosphoserine was used as a marker during electrophoresis. Ninhydrinstained spots were cut out and counted in a toluene scintillation liquid as described above.

The protein content of the samples was measured by the method of Lowry, Rosebrough, Farr \& Randall (1951) using bovine serum albumin as the standard.

\section{Results}

\section{Enzyme purification}

DEAE-Sephadex chromatography of the epididymal protein kinase preparation (Text-fig. 1) gave one major peak of enzymic activity (fractions 23-40) that was retained by the column (kinase B) and a significant peak of activity that was not retained by the column (kinase A). When protein kinase $\mathrm{A}$ was re-chromatographed, both the kinases $\mathrm{A}$ and $\mathrm{B}$ were obtained, the elution profile and the ratio of the two activities being nearly identical to those shown in Text-fig. 1. A similar profile was shown when the kinase A obtained after the first re-chromatography was subjected to further chromatography (data not shown). This result indicates that kinases $A$ and $B$ may be in equilibrium, the ratio of activity at equilibrium being approximately $25: 75$ respectively.

Protein kinase B resolved into two enzymic species (kinases I and II) when subjected to hydroxyapatite chromatography (Text-fig. 2). Fractions containing kinase I (fractions 15-20) and kinase II (fractions 23-31) were pooled separately and each pool dialysed against 5 mM-sodium glycerophosphate-HCl buffer, $\mathrm{pH} 6 \cdot 5-50 \mathrm{~mm}-2$-mercaptoethanol-30\% glycerol-0.1 $\mathrm{M}$-sucrose. The dialysed enzyme preparations were preserved at $-10^{\circ} \mathrm{C}$ and used for subsequent studies unless otherwise stated. Under this condition of storage the enzymic activities were stable for at least 3 months. At least two different batches of the partly purified enzyme preparations were used for the studies reported here.

Results of a typical enzyme purification are shown in Table 1. Re-chromatography of kinases I and II on hydroxyapatite chromatography yielded a single peak of activity with each enzyme preparation. 


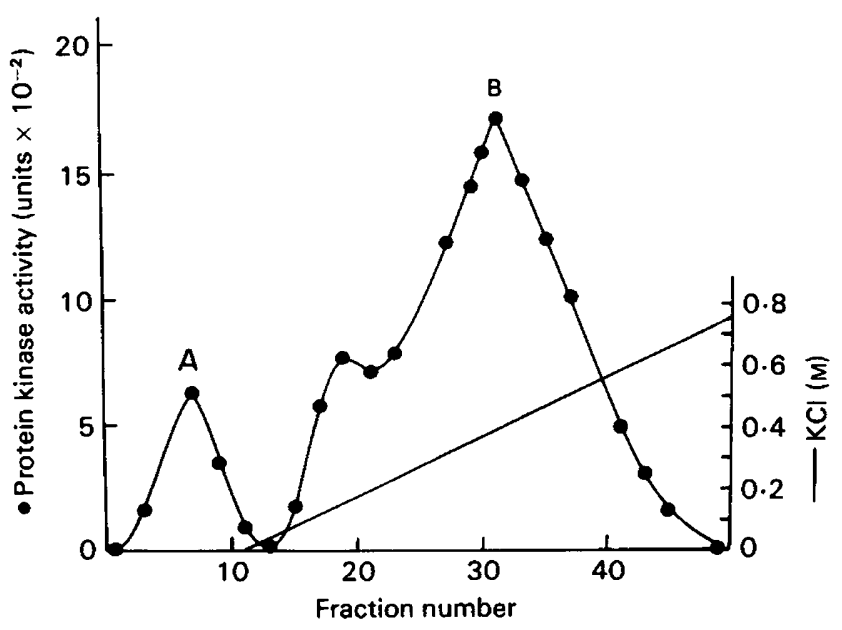

Text-fig. 1. DEAE-Sephadex chromatography of rat epididymal tissue (washed) showing the kinase A and B peaks. An aliquot of $50 \mu \mathrm{l}$ from each fraction was assayed for protein kinase activity under the standard assay conditions. The data are representative of 4 such experiments.

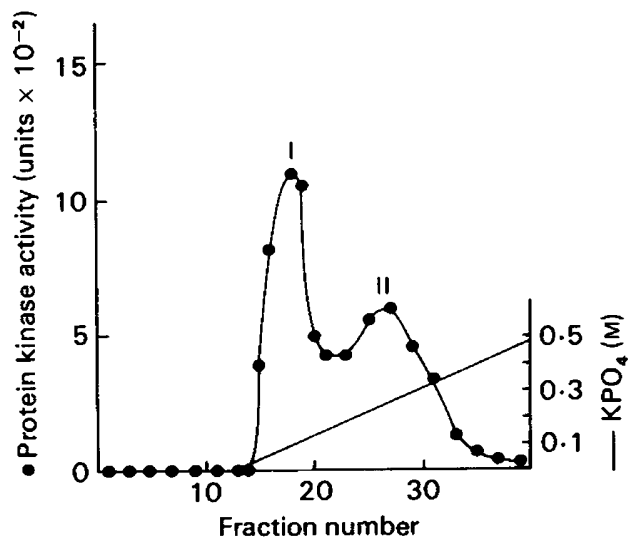

Text-fig. 2. Hydroxyapatite chromatography of rat epididymal cytosolic protein kinase B. An aliquot of $50 \mu \mathrm{l}$ of each fraction was assayed for protein kinase activity under the standard assay conditions. The data are representative of 4 such experiments.

\section{Properties of epididymal protein kinases}

The amount of protamine phosphorylated by both protein kinase I and II increased linearly with time over $30 \mathrm{~min}$. A proportional increase in the activity of the enzymes was observed with as much as 95 and 230 units of kinase I and II respectively. Cyclic AMP at a relatively low concentration $(1 \mu \mathrm{M})$ stimulated the activities of both the kinases to nearly $100 \%$ and the apparent $K_{\mathrm{m}}$ values of kinases I and II (determined by direct plot of the data) for cyclic AMP were 70 and $170 \mathrm{~nm}$ respectively (Text-fig. 3a). Both the enzymes showed higher affinity for activation by cyclic AMP compared to cyclic GMP, cyclic CMP and cyclic UMP (data not shown).

Optimum $p H$. Both the enzymes showed maximal activity at pH 6.0-6.5 (Text-fig. 3b). 
Table 1. Summary of the purification of protein kinases from rat epididymal cytosol

\begin{tabular}{|c|c|c|c|c|c|}
\hline Fraction & $\begin{array}{l}\text { Protein } \\
\text { (mg) }\end{array}$ & $\begin{array}{c}\text { Total } \\
\text { activity } \\
\text { (units } \times \\
10^{-3} \text { ) }\end{array}$ & $\begin{array}{l}\text { Specific } \\
\text { activity } \\
\text { (units/mg } \\
\text { protein } \\
\times 10^{-3} \text { ) }\end{array}$ & $\begin{array}{c}\text { Recovery } \\
\text { (\%) }\end{array}$ & $\begin{array}{l}\text { Purification } \\
\qquad(x)\end{array}$ \\
\hline $\begin{array}{l}\text { Epididymal supernate, } \\
20000 \mathrm{~g} \text { (Step 1) }\end{array}$ & 22.5 & 282 & 12.5 & 100 & 1 \\
\hline $\begin{array}{l}\text { DEAE-Sephadex } \\
\text { kinase peak B } \\
\text { (Step 2) }\end{array}$ & 2.8 & 799 & 285 & 284 & 23 \\
\hline \multicolumn{6}{|l|}{$\begin{array}{l}\text { Hydroxyapatite } \\
\text { chromatography } \\
\text { (Step 3) }\end{array}$} \\
\hline Kinase I & $1 \cdot 2$ & 196 & 163 & 70 & 13 \\
\hline Kinase II & 0.23 & 70 & 307 & 25 & 25 \\
\hline
\end{tabular}

The protein kinases were isolated from $3 \mathrm{~g}$ of adult rat epididymides. The activities of all the fractions were measured under the standard assay conditions. One unit of the enzyme was defined as the amount of activity which caused the transfer of $1 \mathrm{pmol}{ }^{32} \mathrm{P}$ from $\left[\gamma-{ }^{32} \mathrm{P}\right] \mathrm{ATP}$ to the recovered protein under the standard assay conditions. The data are representative of 4 such experiments.
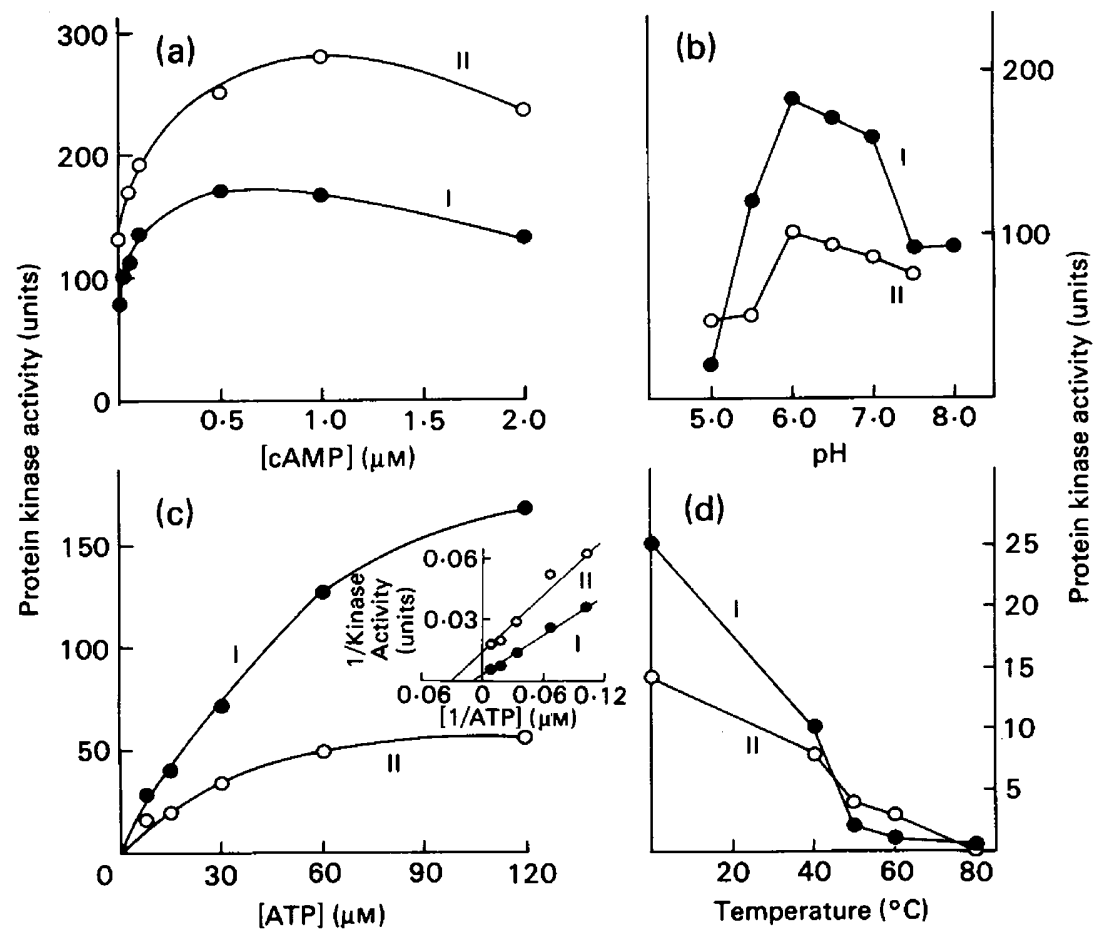

Text-fig. 3. Effect of (a) cyclic AMP concentrations, (b) pH, (c) ATP concentrations and (d) heat on the activity of protein kinases I and II from rat epididymal tissue. Standard assay conditions were used, and a Lineweaver-Burk plot is given as an inset to (c). The data are representative of $3(a, b, c)$ or 2 (d) experiments. 
Table 2. Sensitivity of two rat epididymal protein kinases to metal ions

\begin{tabular}{|c|c|c|c|c|}
\hline \multirow[b]{3}{*}{ System } & \multicolumn{4}{|c|}{ Enzyme activity } \\
\hline & \multicolumn{2}{|c|}{ Kinase I } & \multicolumn{2}{|c|}{ Kinase II } \\
\hline & Units & $\%$ & Units & $\%$ \\
\hline Complete & 40 & 100 & 36 & 100 \\
\hline Without $\mathbf{M g}^{2+}$ & $5 \cdot 3$ & 13 & $7 \cdot 8$ & 22 \\
\hline$+\operatorname{EDTA}(5 \mathrm{~mm})$ & 0 & 0 & 0 & 0 \\
\hline$+\mathrm{Mn}^{2+}(2 \mathrm{mM})$ & 28 & 70 & 8 & 22 \\
\hline$+\mathbf{M n}^{2+}(10 \mathrm{mM})$ & $11 \cdot 3$ & 28 & 1.4 & 3 \\
\hline$+\mathrm{Co}^{2+}(2 \mathrm{mM})$ & 13.5 & 34 & 19.4 & 54 \\
\hline$+\mathrm{Co}^{2+}(10 \mathrm{~mm})$ & 13.5 & 34 & 20 & 56 \\
\hline$+\mathrm{Ca}^{2+}(2 \mathrm{~mm})$ & 2.4 & 6 & 0 & 0 \\
\hline$+\mathrm{Zn}^{2+}(2 \mathrm{mM})$ & 0 & 0 & 0 & 0 \\
\hline \multirow{2}{*}{\multicolumn{5}{|c|}{ With $p$-Chloromercuriphenylsulphonic }} \\
\hline & $7 \cdot 2$ & 18 & 8 & 22 \\
\hline
\end{tabular}

The standard assay system was used except for the omissions or additions indicated. Each value is the mean of duplicate determinations differing by less than $10 \%$. The data are representative of 3 such experiments.

However, further increase of $\mathrm{pH}$ up to 7.5 caused greater decrease in the activity of kinase I than kinase II.

ATP concentration. The apparent $K_{\mathrm{m}}$ value for ATP (Text-fig. $\left.3 \mathrm{c}\right)$ of kinase I $(120 \mu \mathrm{M})$ was higher than that of kinase II $(30 \mu \mathrm{M})$. Due to an inadequate supply of $\left[\gamma^{32} \mathrm{P}\right] \mathrm{ATP}$, it has not been possible to use a saturating concentration of the labelled substrate in the standard assays. All the enzymic characteristics of the isoenzymes were therefore measured at a rate limiting concentration (15 $\mu \mathrm{M})$ of ${ }^{32} \mathrm{P}$-labelled ATP (unless otherwise specified).

Metal ions. As shown in Table 2, EDTA (5 mM) completely inhibited the activity of the protein kinases, indicating that enzymic activities are dependent on metal ions. Both kinases were activated maximally by $\mathrm{Mg}^{2+} . \mathrm{Mn}^{2+}$ and $\mathrm{Co}^{2+}$ could substitute partly for $\mathrm{Mg}^{2+}$ whereas $\mathrm{Ca}^{2+}$ and $\mathrm{Zn}^{2+}$ resulted in further inhibition. Both the enzymes were activated maximally at 10 $\mathrm{mM}-\mathrm{MgCl}_{2}$ and the apparent $K_{\mathrm{m}}$ value of both the enzymes for $\mathrm{Mg}^{2+}$ was approximately $2 \mathrm{mM}$ (data not shown). $p$-Chloromercuriphenylsulphonic acid strongly inhibited the activity of the kinase, indicating that $-\mathrm{SH}$ group(s) of the enzymes are essential for enzymic activity. The effects of various concentrations of $\mathrm{Zn}^{2+}$ on the $\mathrm{Mg}^{2+}$ activated kinases were determined (data not shown). Zinc chloride $(0.5 \mathrm{~mm})$ caused more than $50 \%$ inhibition of the activity of both the enzymes.

Substrate specificity. Both kinases showed high specificity for the phosphorylation of protamine and histones (Table 3 ) but caused little phosphorylation of the acidic proteins, casein and phosvitin. The apparent $K_{\mathrm{m}}$ value of both the kinases for protamine was approximately 100 $\mu \mathrm{g} / \mathrm{ml}$ (data not shown).

Heat stability. Kinase I was more sensitive to heat treatment than kinase II (Text-fig. $3 \mathrm{~d}$ ). Both the enzymes lost activity nearly completely when heated at $80^{\circ} \mathrm{C}$ for $10 \mathrm{~min}$.

Characterization of enzymically phosphorylated protamine. There was no appreciable loss of radioactivity from the ${ }^{32} \mathrm{P}$-labelled trichloroacetic acid-insoluble precipitate when heated in $5 \%$ TCA at $90^{\circ} \mathrm{C}$ for $15 \mathrm{~min}$, indicating that ${ }^{32} \mathrm{P}$ had not been incorporated into the nucleic acids. The observed radioactivity in protein was not due to incorporation of ${ }^{32} \mathrm{P}$ into phospholipids (Table 4). The insensitivity of the incorporated ${ }^{32} \mathrm{P}$ to hydroxylamine largely ruled out an acyl-phosphate linkage as described for the $\left(\mathrm{Na}^{+}+\mathrm{K}^{+}\right)$-dependent ATPase (Hokin, Sastry, Glasworthy \& Yoda, 1965), a well characterized phosphoprotein of the plasma membrane. All the radioactivity of the ${ }^{32} \mathrm{P}$-labelled protamine was associated with alkali-labile phosphoester bonds. 
Table 3. Substrate specificity of the two rat epididymal protein kinases

\begin{tabular}{lccc}
\hline & & \multicolumn{2}{c}{$\begin{array}{c}\text { Protein kinase activity } \\
\text { (Units) }\end{array}$} \\
\cline { 2 - 4 } \multicolumn{1}{c}{ Substrate } & $\begin{array}{c}\text { Amount } \\
(\mu \mathrm{g})\end{array}$ & Kinase I & Kinase II \\
\hline None & 0 & 8 & 6 \\
Calf thymus histones & 50 & 17 & 13 \\
& 250 & 15 & 12 \\
Protamine & 50 & 40 & 30 \\
Casein & 250 & 62 & 40 \\
& 50 & 3 & 6 \\
Phosvitin & 250 & 5 & 3 \\
& 50 & 3 & 5 \\
& 250 & 7 & 7 \\
\hline
\end{tabular}

Standard assay conditions were used except for the replacement of $100 \mu \mathrm{g}$ of protamine by the various substrates indicated. Each value is the mean of duplicate determinations differing by less than $10 \%$. The data are representative of 3 such experiments.

Table 4. Alkali lability of the phosphoester bonds of $\left.{ }^{[32} \mathrm{P}\right]$ protamine

\begin{tabular}{lcc}
\hline & \multicolumn{2}{c}{$\begin{array}{c}\text { Protein kinase activity } \\
\text { (Units) }\end{array}$} \\
\cline { 2 - 3 } \multicolumn{1}{c}{ Treatment } & Kinase I & Kinase II \\
\hline Control & 47 & 23 \\
Methanol : chloroform $(1: 2 \mathrm{v} / \mathrm{v})$ & 43 & 20 \\
Hydroxylamine $(0.8 \mathrm{M})$ & 45 & 21 \\
$\mathrm{NaCl}(0.64 \mathrm{M})$ & 45 & 20 \\
$\mathrm{NaOH}(1 \mathrm{~N})$ & 0 & 0 \\
\hline
\end{tabular}

${ }^{32} \mathrm{P}$-Labelled protamine from the untreated 'control' tubes was washed with $5 \%$ trichloroacetic acid as described in 'Materials and Methods'. The labelled protamine was treated with methanol:chloroform $(1: 2 \mathrm{v} / \mathrm{v})$ and hot $\mathrm{NaOH}(1 \mathrm{~N})$ according to Kinzel \& Mueller (1973) and with 0.8 M-hydroxylamine according to Hokin et al. (1965). Each value is the mean of duplicate determinations differing by less than $10 \%$. The data are representative of 2 such experiments.

${ }^{32}$ P-labelled trichloroacetic acid-insoluble products obtained by phosphorylating protamine with the isolated epididymal protein kinases were fractionated by polyacrylamide gel electrophoresis (data not shown). One radioactive peak which corresponded to the protamine band was obtained for each kinase. The data indicate that the kinases specifically cause the phosphorylation of protamine, and do not catalyse the phosphorylation of any contaminating proteins (if any) derived from the enzyme and the protamine preparations. Amino acid analysis of the ${ }^{32} \mathrm{P}$-labelled protamine demonstrated that both the kinases catalysed the phosphorylation of serine residues of the protein (data not shown).

Subcellular distribution. The distribution of the protein kinase activity in the subcellular fractions of epididymis was determined by a differential sedimentation technique. The specific activity (units/mg protein) was distributed as 332 in nuclei, 422 in mitochondria, 31 in 
microsomes and $1339(83 \%)$ in the supernatant. The epididymal protein kinases I and II would therefore appear to be of cytosolic origin.

Epididymal fluid contamination. Protein kinase activity has been demonstrated in rat epididymal plasma (Majumder, 1981). To determine the contribution of the $1 \%$ contamination by epididymal fluid towards the total epididymal cytosolic protein kinase activity, freshly extracted epididymal fluid and washed epididymal tissue were homogenized and centrifuged at $22000 \mathrm{~g}$ for $60 \mathrm{~min}$. The resulting supernates were dialysed against $15 \mathrm{~mm}$-Tris- $\mathrm{HCl} \mathrm{pH}$ $7.0-50 \mathrm{~mm}-2$-mercaptoethanol-15\% glycerol before assay of protein kinase activity under the standard assay conditions. The contaminating epididymal fluid contributed less than $1 \%$ of the total cytosolic kinase activity of the epididymis (data not shown).

\section{Discussion}

The present studies demonstrate that the cyclic AMP-dependent protein kinase activity in the rat epididymal cytosol consists of at least two separate enzyme species (I and II). Both the enzymes are activated by cyclic AMP and have high specificities for the basic proteins rather than the acidic proteins as protein substrates. That the two enzyme preparations contained different enzyme molecules was indicated by their separate elution profile after re-chromatography on hydroxyapatite and differences in certain enzymic characteristics such as $\mathrm{pH}$ activation profiles, $K_{\mathrm{m}}$ for cyclic AMP and ATP and heat-sensitivity. The enzymic activities of the epididymal fraction increased markedly (approx. 3-fold) following DEAE-Sephadex chromatography (Table 1), indicating that the rat epididymis may contain a protein kinase inhibitor (Walsh et al., 1971; Szmigielski, Alessandro \& Costa, 1977) or other interfering substances that were removed by the chromatographic procedure.

Studies from a large number of tissues indicate that cyclic AMP-dependent protein kinase holoenzyme (RC) consists of a catalytic (C) and a regulatory (R) subunit (Langan, 1973). Cyclic AMP activates the enzyme by binding with subunit $\mathrm{R}$ and thereby causes the dissociation of $\mathrm{C}$ which is the active form of the enzyme. It is possible that the epididymal cytosolic protein kinase I and II, like the other cyclic AMP-dependent protein kinases, may be a complex of Rand $\mathrm{C}$ subunits. Certain differences in the characteristics of these kinases may relate to differences in their subunit composition (Corbin, Brostrom, King \& Krebs, 1972).

Human seminal plasma has been shown to be a rich source of protein kinase (Majumder, 1978). Little is known about the origin of the enzyme in the seminal plasma. In view of the finding that rat epididymal plasma possesses a cyclic AMP-dependent protein kinase (Majumder, 1981), it is likely that epididymal fluid contributes, at least in part, to the seminal plasma protein kinase activity. It is possible that the epididymis, known to be secretorily active in other ways, may release cytosolic protein kinase(s) in the lumen. Further studies are required to elucidate the structural and functional relationship between the epididymal plasma and cytosolic protein kinases.

Male reproductive organs and their secretions are rich sources of $\mathrm{Zn}^{2+}$ (Byar, 1974). Zinc inhibits sperm motility (Janick, Zeitz \& Whitmore, 1971; Tang \& Hoskins, 1975) and is a potent inhibitor of bovine sperm phosphoprotein phosphatase (Tang \& Hoskins, 1975) and cyclic AMP-dependent protein kinases derived from human seminal plasma (Majumder, 1978), rat epididymal sperm surface (Majumder, 1981) and epididymal cytosol (Table 2). As postulated earlier (Majumder, 1978), $\mathrm{Zn}^{2+}$ may have an important role for the regulation of phosphorylation and dephosphorylation of sperm and other proteins in the male and female genital tracts that may participate in sperm motility and fertility.

We thank the Indian Council of Medical Research and Bhabha Atomic Research Centre for a research fellowship (R.B.) and Professor B. K. Bachhawat for his interest in this study. 


\section{References}

Bernard, E.A. \& Wassermann, G.C. (1972) Protein kinase activities in rat epididymis. Effects of maturation and testosterone treatment. Biochem. Biophys. Res. Commun. 49, 434-440.

Bray, G.A. (1960) A simple efficient liquid scintillator for counting aqueous solutions in a liquid scintillation counter. Analyt, Biochem. 1, 279-285.

Byar, D.P. (1974) Zinc in male sex accessory organs: distribution and hormonal response. In Male Accessory Sex Organs-Structure and Function in Mammals, pp. 161-171. Ed. D. Brandes. Academic Press, New York.

Corbin, J.D., Reimann, E.M., Walsh, D.A. \& Krebs, E.G. (1970) Activation of adipose tissue lipase by skeletal muscle cyclic adenosine $3^{\prime}-5^{\prime}$ monophosphate stimulated protein kinase. J. biol. Chem. 245, 4849-4851.

Corbin, J.D., Brostrom, C.O., King, C.A. \& Krebs, E.G. (1972) Studies on the adenosine $3^{\prime}-5^{\prime}$-monophosphate-dependent protein kinases of rabbit skeletal muscle. J. biol. Chem. 247, 7790-7798.

Hamilton, D.W. (1975) Structure and function of the epithelium lining the ductuli efferentes, ductus epididymis and ductus deferens in the rat. In Handbook of Physiology, Sect. 7; Endocrinology; Vol. V, Male Reproductive System, pp. 259-301. Eds D. W. Hamilton \& E. B. Astwood. American Physiological Society, Washington, D.C.

Hogeboom, G.H. (1955) Fractionation of cell components of animal tissues. In Methods in Enzymology, Vol. I, pp. 16-19. Eds S. P. Colowick \& N. O. Kaplan. Academic Press, New York.

Hokin, L.E., Sastry, P.S., Glasworthy, P.R. \& Yoda, A. (1965) Evidence that a phosphorylated intermediate in a brain transport adenosine triphosphatase is an acylphosphate. Proc. natn. Acad. Sci. U.S.A. 54, 177-184.

Janick, J., Zeitz, L. \& Whitmore, W.F., Jr (1971) Seminal fluid and spermatozoon zinc levels and their relationship to human spermatozoon motility. Fert. Steril. 22, 573-580.

Kadohama, N. \& Turkington, R.W. (1974) Changes in acidic chromatin proteins during the hormone-dependent development of rat testis and epididymis. J. biol. Chem. 249, 6225-6233.

Kinzel, V. \& Mueller, G.C. (1973) Phosphorylation of surface protiens of Hela Cells using an exogenous protein kinase and $\left[\gamma-\mathbf{P}^{32}\right]$-ATP. Biochim. Biophys. Acta 322, 337-351.
Kleinsmith, L.J. (1975) Phosphorylation of non-histone proteins in the regulation of chromosome structure and function. J. cell. Physiol. 85, 459-476.

Langan, T.A. (1973) Protein kinases and protein kinase substrates. Adv. Cyclic Nucleotide Res. 3, 99-141.

Lowry, O.H., Rosebrough, N.J., Farr, A.L. \& Randall, R.J. (1951) Protein measurement with the Folin phenol reagent. J. biol. Chem. 193, 265-275.

Majumder, G.C. (1978) Characterization of a protein kinase from human seminal plasma. Biochem. Biophys. Res. Commun. 81, 1217-1226.

Majumder, G.C. (1981) Enzymic characteristics of an ecto-cyclic AMP-dependent protein kinase in rat epididymal spermatozoa. Biochem.J. 195, 111-117.

Majumder, G.C. \& Biswas, R. (1979) Evidence for the occurrence of an ecto-(adenosine triphosphatase) in rat epididymal spermatozoa. Biochem. J. 183, 737743.

Majumder, G.C. \& Turkington, R.W. (1972) Hormonedependent phosphorylation of ribosomal and plasma membrane proteins in mouse mammary gland in vitro. J. biol. Chem. 247, 7207-7217.

Paynim, S. \& Chalkley, R. (1969) High resolution acrylamide gel electrophoresis of histones. Arch. Biochem. Biophys. 130, 337-346.

Szmigielski, A., Alessandro, G. \& Costa, E. (1977) Endogenous protein kinase inhibitors. J. biol. Chem. 252, 3848-3853.

Tang, F.Y. \& Hoskins, D.D. (1975) Phosphoprotein phosphatase of bovine epididymal spermatozoa. Biochem. Biophys. Res. Commun. 62, 328-335.

Turkington, R.W. \& Riddle, M. (1969) Hormonedependent phosphorylation of nuclear proteins during mammary gland differentiation in vitro. J. biol. Chem. 244, 6040-6046.

Turkington, R.W., Majumder, G.C., Kadohama, N., MacIndoe, J.H. \& Frantz, W.L. (1973) Hormonal regulation of gene expression in mammary cells. Recent Prog. Horm. Res. 29, 417-455.

Walsh, D.A. \& Cooper, R.H. (1979) The physiological regulation and function of CAMP-dependent protein kinases. Biochem. Actions Horm. 6, 417-455.

Walsh, D.A., Ashby, C.D., Gonzalez, C., Calkins, D., Fisher, E.H. \& Krebs, E.C. (1971) Purification and characterization of a protein kinase inhibitor of adenosine $3^{\prime}-5^{\prime}$-monophosphate dependent protein kinase. J. biol. Chem. 246, 1977-1985.

Received 1 June 1981 